\title{
Modulation of Mitochondrial ER $\beta$ Expression Inhibits Triple-Negative Breast Cancer Tumor Progression by Activating Mitochondrial Function
}

\author{
In-Sung Songa Yu Jeong Jeong ${ }^{\mathrm{a}}$ Seung Hun Jeong ${ }^{\mathrm{a}} \quad \mathrm{Ji}_{\text {Eun Kim }}^{\mathrm{a}}$ Jin Han ${ }^{\mathrm{b}}$ \\ Tae-Hyun Kim ${ }^{c}$ Sung-Wuk Jang ${ }^{a}$
}

\begin{abstract}
aDepartment of Biomedical Sciences, University of Ulsan College of Medicine, Asan Medical Center, Seoul, Korea, 'National Research Laboratory for Mitochondrial Signaling, Department of Physiology, College of Medicine, Cardiovascular and Metabolic Disease Center, Inje University, Busan, Korea, 'Breast \& Thyroid Center, Department of Surgery, College of Medicine, Inje University, Busan Paik Hospital, Busan, Korea
\end{abstract}

\section{Key Words}

$\mathrm{ER} \beta \cdot \operatorname{mitoER} \beta \cdot$ Triple-negative breast cancer $・$ Mitochondria $\bullet$ Grp75

\begin{abstract}
Background/Aims: Breast cancer is a clinically and molecularly heterogeneous disease. Patients with triple-negative breast cancer (TNBC) have poorer outcomes than those with other breast cancer subtypes due to lack of effective molecular targets for therapy. The present study aimed to the identification of estrogen receptor (ER) $\beta$ as a novel mitochondrial target in TNBC cells, together with underlying mechanisms. Methods: Expression of ER $\beta$ in clinical breast samples were examined by qRT-PCR, immunohistochemistry and immunoblotting. Subcellular distribution and binding of ER $\beta$-Grp75 was determined by confocal microscopic analysis, co-immunoprecipitation experiments, and limited-detergent extraction of subcellular organelles. The effect of mitocondrial ER $\beta$ (mitoER $\beta$ ) overexpression on cell proliferation and cell cycle distribution were assessed CCK-8 assays and FACS. Mitochondrial ROS, membrane potential, and $\mathrm{Ca}^{2+}$ level were measured using the specific fluorescent probes Mito-Sox, TMRE, and Rhod-2AM. The tumorigenic effect of mitoER $\beta$ overexpression was assessed using an anchorage-independent growth assay, sphere formation and a mouse orthotopic xenograft model. Results: ER $\beta$ expression was lower in tumor tissue than in adjacent normal tissue of patients with breast cancer, and low levels of mitochondrial ER $\beta$ (mitoER $\beta$ ) also were associated with increased tumor recurrence after surgery. Overexpression of mitoER $\beta$ inhibited the proliferation of TNBC cells and tumor masses in an animal model. Moreover, overexpression of mitoER $\beta$ increased ATP production in TNBC cells and normal breast MCF10A
\end{abstract}

I. Song and $\mathrm{Y}$. Jeong contributed equally to this paper.

\begin{tabular}{ll}
\hline Sung-Wuk Jang, PhD & Department of Biomedical Sciences, University of Ulsan College of Medicine, Asan Medical Center, \\
and Tae-Hyun Kim, MD, PhD & 88, Olympic-ro 43-gil, Songpa-gu, Seoul 138-736 (Korea) \\
& Tel. +82-2-3010-2088, E-Mail swjang@amc.seoul.kr; kitah@hanmail.net
\end{tabular}




\section{Cellular Physiology Cell Physiol Biochem 2019;52:468-485 \\ \begin{tabular}{ll|l} 
and Biochemistry $\begin{array}{l}\text { DOl: 10.33594/000000034 } \\
\text { Published online: 15 March 2019 }\end{array}$ & $\begin{array}{l}\text { O } 2019 \text { The Author(s). Published by } \\
\text { Cell Physiol Biochem Press GmbH\&Co. KG }\end{array}$ \\
\cline { 2 - 3 } & Song
\end{tabular} \\ Song et al.: mitoER $\beta$ Regulates Mitochondrial Function in TNBC}

cells, with the latter completely reversed by mitoER $\beta$ knockdown in MCF10A cells. Grp75 was found to positively regulate ER $\beta$ translocation into mitochondria via a direct interaction. Coimmunoprecipitation and subcellular fractionation experiments revealed that ER $\beta-G r p 75$ complex is stable in mitochondria. Conclusion: These results suggest that the up-regulation of mitoER $\beta$ in TNBC cells ensures proper mitochondrial transcription, activating the OXPHOS system to produce ATP. Studying the effects of mitoER $\beta$ on mitochondrial activity and specific mitochondrial gene expression in breast cancer might help predict tumor recurrence, inform clinical decision-making, and identify novel drug targets in the treatment of TNBC.

(C) 2019 The Author(s). Published by

Cell Physiol Biochem Press GmbH\&Co. KG

\section{Introduction}

Breast cancer is the most common cancer among women worldwide, with 1.7 million women newly diagnosed in 2012. Triple-negative breast cancer (TNBC) is a subtype of breast cancer, defined classically by the lack of expression of estrogen receptor (ER), progesterone receptor (PR), and HER2. TNBC, which affects 15-20\% of women newly diagnosed with breast cancer worldwide, has an aggressive phenotype, a high metastasis rate, and poor prognosis. Compared with other breast cancer subtypes, TNBC tumors are frequently larger and less differentiated and metastasize within 5 years of diagnosis $[1,2]$. The lack of targeted therapies and the poor prognosis of patients with TNBC have led to efforts to identify molecular targets for the treatment of this disease.

Anticancer drugs targeting the mitochondria may overcome metastasis and resistance to conventional chemotherapeutic agents [3-6]. The mitochondria are the major cellular sites of energy generation, are important in maintaining calcium homeostasis, and are involved in integrating the intrinsic and extrinsic apoptosis pathways [7]. Mitochondrial functions can be affected by defects in mitochondrial DNA (mtDNA), alterations in nuclear DNAencoded mitochondrial proteins, or drug-induced damage to mitochondrial membranes. Defects in mtDNA, including mutations and low mtDNA copy number, have been implicated in various neurodegenerative disorders, aging, and cancer [8,9], and have been associated with increased metastasis and poor prognosis $[10,11]$. In addition, many nuclear proteins, including heat shock proteins $[12,13]$, cyclophilin D [14], mitochondrial calcium uniporter [15], and ER $\beta$ are imported into mitochondria, where they contribute to the maintenance and regulation of mitochondrial function [16]. ER $\beta$ was shown to localize to the mitochondria in both ligand-dependent and -independent manners [17], and human mtDNA was shown to contain putative estrogen response elements (EREs) [18]. Moreover, importation of ER $\beta$ into the mitochondria of breast cancer cells has been found to lead to the expression of mitochondrial genes encoding cytochrome c oxidase subunits I and II via transcriptional activation $[16,19]$. ER $\beta$ was also shown to inhibit epithelial to mesenchymal transition (EMT) and the invasiveness of TNBC cells [20]. The level of ER $\beta$ expression was found to be lower in breast tumors than in adjacent normal tissue, whereas ER $\alpha$ expression was found to be higher in breast cancer than in normal mammary epithelial cells [21-25]. However, the prognostic and therapeutic significance of mitochondrial ER $\beta$ (mitoER $\beta$ ) in ER $\alpha$-negative breast cancer, especially the roles of mitoER $\beta$ in TNBC metastasis and prognosis, remain incompletely understood.

This study showed that overexpression of mitoER $\beta$ activated mitochondrial gene expression in TNBC cells, which utilize primary glycolysis rather than mitochondrial oxidative phosphorylation (OXPHOS) to produce adenosine triphosphate (ATP). This study also found that TNBC cells have glycolysis properties distinct from luminal type, as indicated by their lower mitochondrial potential and decreased $\mathrm{Ca}^{2+}$ and ROS levels. These properties of TNBC cells contribute to the reduction of tumorigenic ability by the overexpression of mitoER $\beta$. Furthermore, the depletion of ER $\beta$ in patients with breast cancer resulted in increased metastatic tumor growth due to a reduction in mitochondrial function, suggesting that ER $\beta$ is required for mitochondrial gene expression and ATP production via OXPHOS. In addition, ER $\beta$ overexpression impaired tumor growth in vivo, further implicating ER $\beta$ in 


\section{Cellular Physiology Cell Physiol Biochem 2019;52:468-485 \\ \begin{tabular}{ll|l} 
and Biochemistry & $\begin{array}{l}\text { DOl: 10.33594/000000034 } \\
\text { Published online: 15 March 2019 }\end{array}$ & $\begin{array}{l}\text { O 2019 The Author(s). Published by } \\
\text { Cell Physiol Biochem Press GmbH\&Co. KG }\end{array}$ \\
\cline { 2 - 3 } &
\end{tabular} \\ Song et al.: mitoER $\beta$ Regulates Mitochondrial Function in TNBC}

the maintenance of mitochondrial function of breast cells. Taken together, these findings suggested that mitochondria-targeting ER $\beta$ maintains mitochondrial function in breast cells by promoting mitochondrial gene expression. These findings led to the identification of a novel mitochondrial target in TNBC cells. Drugs targeting this molecule may eliminate TNBC cells, improving therapeutic responses in patients with this breast cancer subtype.

\section{Materials and Methods}

\section{Cell culture and antibodies}

The human breast cancer MCF7, MDA-MB-231, and MDA-MB-436 cell lines and the normal MCF10A cell line were obtained from the American Type Culture Collection (Manassas, VA). The MCF7 and MDAMB-231 cell lines were cultured in RPMI1640 medium supplemented with $10 \%$ fetal bovine serum (FBS); MDA-MB-436 cells were cultured in DMEM medium supplemented with 10\% FBS; and MCF10A cells were cultured in DMEM/F12 Ham's Mixture supplemented with 5\% FBS (Sigma), $20 \mathrm{ng} / \mathrm{ml}$ EGF (Sigma, Saint Louis, MO), $10 \mu \mathrm{g} / \mathrm{ml}$ insulin (Sigma, Saint Louis, MO), $0.5 \mathrm{mg} / \mathrm{ml}$ hydrocortisone (Sigma, Saint Louis, MO), $100 \mathrm{ng} / \mathrm{ml}$ cholera toxin (Sigma, Saint Louis, MO), 100 units/ml penicillin, and $100 \mu \mathrm{g} / \mathrm{ml}$ streptomycin. All cells were cultured at $37^{\circ} \mathrm{C}$ in a $5 \% \mathrm{CO}_{2}$ humidified incubator. Antibodies against Grp75, His, and tubulin were purchased from Cell Signaling Technology (Danvers, MA); and antibodies against Prx3, ER $\beta$, and GST were from Abclone (Seoul, Korea), Abcam (Cambridge, UK), and Santacruz Biotechnology (Santa Cruz, CA), respectively.

\section{Plasmids}

Full-length human ERß (NM_001291723) and Grp75 (NM_004134) cDNAs were obtained from the 21C HUMAN GENE BANK, Genome Research Center of Korea Research Institute of Bioscience and Biotechnology (KRIBB), South Korea. ER $\beta$ was subcloned into the plasmids pCGN-HA (kindly provided by Dr. W. Herr, Cold Spring Harbor Laboratory, Cold Spring Harbor, NY) and pEBG-GST (kindly provided by Dr. Y. Liu, NIA, National Institutes of Health, Bethesda, MD) to construct HA-tagged and GST-fused plasmids, respectively. ER $\beta$ was also subcloned into the vector pCGN-HA-mito, which includes the mitochondrial targeting sequence of SOD2 protein. The ER $\beta$-deletion mutants $E R \beta \triangle N$ (a.a. 145-530) and $E R \beta \triangle C$ (a.a. 1-468) were subcloned into pCGN-HA, and Grp75 was subcloned into pcDNA6.1-mycHis (Invitrogen, Carlsbad, CA) to construct the His-tagged plasmid.

\section{Protein isolation and western blotting}

Cells were lysed in lysis buffer A (20 mM HEPES [pH 7.5], $150 \mathrm{mM} \mathrm{NaCl}, 1 \mathrm{mM}$ EDTA, 2 mM EGTA, 1\% Triton X-100, 10\% glycerol, and protease cocktail [Sigma]), and the lysate was cleared by centrifugation at $10,000 \times \mathrm{g}$ for 10 minutes. Proteins were separated by sodium dodecyl sulfate polyacrylamide gel electrophoresis, transferred onto nitrocellulose membranes, blocked with 5\% skim milk in $0.01 \mathrm{M}$ TBS (pH 7.5) containing $0.5 \%$ Tween 20 , and blotted with the appropriate primary antibodies. The antibodiesantigen complexes were detected by chemiluminescence (Abclone).

\section{Immunoprecipitation and glutathione S-transferase (GST) precipitation}

For coimmunoprecipitation, MCF7 cells were co-transfected with the expression vectors pCGNHA-ER $\beta$ and pcDNA-Grp75-his using Lipofectamine 3000 (Invitrogen) according to the manufacturer's protocol. Following lysis in lysis buffer A and removal of cellular debris by centrifugation, the lysates were immunoprecipitated with antibodies against ER $\beta$ or Grp75, or normal IgG. Protein G Sepharose beads (GE Healthcare) were added, and the precipitated proteins were analyzed by immunoblotting with the appropriate antibodies. MCF7 cells were also transfected with pEBG-GST-ER $\beta$ and pEBG-GSTER $\beta \triangle C$, expressing the ER $\beta$-deletion mutants using Lipofectamine 3000, and the GST fusion proteins were precipitated from cell lysates and analyzed by immunoblotting with anti-GST and anti-Grp75 antibodies.

\section{GST-affinity purification of ERß complex and peptide mass finger printing}

MCF7 cells were transfected with pEBG-GST-ER $\beta$ plasmid for 48 hours and gently lysed in $10 \mathrm{ml}$ of lysis buffer A. The lysate ( $1 \mathrm{~g}$ of total protein) was precipitated with glutathione Sepharose beads for 


\section{Cellular Physiology Cell Physiol Biochem 2019;52:468-485 \\ \begin{tabular}{c|c|c|c|c|} 
DOl: 10.33594/000000034 & 2019 The Author(s). Published by \\
and Biochemistry &
\end{tabular} \\ \begin{tabular}{ll} 
Published online: 15 March 2019 Cell Physiol Biochem Press GmbH\&Co. KG \\
\hline
\end{tabular} \\ Song et al.: mitoER $\beta$ Regulates Mitochondrial Function in TNBC}

3hrs. After four washes with lysis buffer A, the beads were loaded onto a column and rinsed twice with phosphate-buffered saline. The precipitated proteins were separated on $10 \%$ denaturing gels, which were subsequently stained with Coomassie blue staining solution, and the stained bands were subjected to in-gel trypsin digestion. Briefly, the gel bands were excised with a scalpel, destained, dehydrated in acetonitrile, and rehydrated in $10-20 \mu \mathrm{l}$ of $25 \mathrm{mM}$ ammonium bicarbonate containing $10 \mathrm{ng} / \mu \mathrm{l}$ sequencing grade trypsin (Promega, Madison, WI). The gel pieces were incubated at $37^{\circ} \mathrm{C}$ for $15-17 \mathrm{hrs}$. The peptides in each supernatant were transferred to a new tube and extracted by adding $50 \mu \mathrm{l}$ of a solution containing $60 \%$ acetonitrile and $0.1 \%$ trifluoroacetic acid. Each extraction was repeated twice, followed by the addition of $50 \mu \mathrm{l}$ of acetonitrile. The samples were finally reconstituted in $10 \mu \mathrm{l}$ of $0.1 \%$ trifluoroacetic acid and treated with ZipTips containing a $\mathrm{C}_{18}$ resin (Millipore) according to the manufacturer's instructions. The tryptic peptides were subjected to mass spectrometric analysis using a Voyager-DE STR Biospectrometry Workstation (Applied Biosystems, Framingham, MA) equipped with a nitrogen laser.

Measurement of mitochondrial activity and ATP production

Mitochondrial ROS, membrane potential, and $\mathrm{Ca}^{2+}$ level were measured using the specific fluorescent probes Mito-Sox, TMRE, and Rhod-2AM, respectively. Cells were plated and incubated with $1 \mu \mathrm{M}$ Mito-Sox for 20 minutes or with $5 \mu \mathrm{M} \mathrm{TMRE}$, or Rhod-2AM for 30 minutes at $37^{\circ} \mathrm{C}$. The levels of the fluorescent probes were measured using a FACScanto II flow cytometer (BD Biosciences). Basal and mitochondrial ATP levels were measured using the mitochondrial ToxGlo Assay (Promega), according to the manufacturer's protocol. Mitochondrial ATP concentration was measured using ATP bioluminescent assay kits (Sigma), involving firefly luciferin-luciferase, and performed according to the manufacturer's guidelines.

\section{Subcellular fractionation}

For the mitochondrial leak experiments, the cytosolic and mitochondrial fractions were obtained using a ProteoExtract subcellular proteome extraction kit (Calbiochem). Briefly, $2 \times 10^{6}$ cells were harvested, rinsed twice with ice-cold PBS, resuspended in $200 \mu \mathrm{l}$ of extraction buffer 1 containing a protease inhibitor cocktail (PIC), and incubated with gentle agitation at $4^{\circ} \mathrm{C}$ for 10 minutes. The supernatants were separated into pellets and supernatants (cytosolic fraction) by centrifugation at $1000 \times \mathrm{g}$ for 10 minutes. The pellets were resuspended in $200 \mu \mathrm{l}$ of extraction buffer 2 containing PIC, incubated with gentle agitation at $4^{\circ} \mathrm{C}$ for $30 \mathrm{~min}$, and separated into pellets and supernatants (mitochondrial fraction) by centrifugation at $6000 \times \mathrm{g}$ for 10 minutes.

\section{Proliferation assay}

Rate of cell proliferation was determined using 2-(2-methoxy-4-nitrophenyl)-3-(4-nitrophenyl)-5(2, 4-disulfophenyl)-2H-tetrazolium salt assays (WST-8; CCK-8, Dojindo). Briefly, log-phase cells were trypsinized to single-cell suspensions, which were plated onto 96 -well plates at a density of $5 \times 10^{3}$ per well. CCK-8 solution was added to each well. After $1 \mathrm{~h}$, the absorbance at $450 \mathrm{~nm}$ of each well was determined using a Victor III microplate reader (Perkin-Elmer).

\section{Cell cycle analysis}

Cells in log phase were washed twice with PBS, fixed with $70 \%$ ethanol, incubated overnight at $4^{\circ} \mathrm{C}$, and resuspended in freshly prepared propidium iodide staining solution (PBS containing $40 \mu \mathrm{g} / \mathrm{ml}$ DNase-free RNase A [Roche] and $40 \mu \mathrm{g} / \mathrm{ml}$ propidium iodide [Invitrogen]) and incubated at $37^{\circ} \mathrm{C}$ for 30 min. Fluorescence intensity was analyzed by FACscan (BD Biosciences) using CellQuest software. The cell proliferation index (PI) was calculated using the following formula: PI = number of S-, G2-, and M-stage cells / number of total cells $\times 100 \%$. Each experiment was repeated four times.

\section{Small-interfering RNA transfection}

For ER $\beta$ and Grp75 knockdown, small-interfering RNAs for ER $\beta$ (5'- GAA GUG UUA CGA AGU GGG A $-3^{\prime}$ ) and Grp75 (5'- GCU GUC ACC AAC CCA AAC AAU -3') were constructed, with both exhibiting specific knockdown efficiencies $>90 \%$. Cells were transfected with these specific siRNAs or with a nontargeting siRNA (5'- UUC UUC GAA CGU GUC ACG U -3') at final concentrations of $50 \mathrm{nmol} / \mathrm{L}$, for 72 hours with lipofectamine RNAimax, according to the manufacturer's protocol. 


\section{Cellular Physiology Cell Physiol Biochem 2019;52:468-485 \\ \begin{tabular}{ll|l|l|l} 
DOl: 10.33594/000000034 & ( 2019 The Author(s). Published by \\
\hline
\end{tabular} \\ and Biochemistry Published online: 15 March 2019 Cell Physiol Biochem Press GmbH\&Co. KG \\ Song et al.: mitoER $\beta$ Regulates Mitochondrial Function in TNBC}

\section{Immunohistochemistry of tissue samples}

Tissue samples were fixed overnight in $10 \%$ neutral buffered formalin, embedded in paraffin, and processed as $5 \mu \mathrm{m}$ thick sections. Deparaffinized sections were briefly heated for $4 \mathrm{~min}$ in a pressure cooker containing $10 \mathrm{mM}$ citrate buffer ( $\mathrm{pH}$ 6.0) for antigen retrieval. Subsequent procedures were performed at room temperature. The sections were pretreated with $3 \% \mathrm{H}_{2} \mathrm{O}_{2}$ in $0.1 \mathrm{M}$ Tris-buffered saline (TBS, pH 7.4) for 30 min to quench endogenous peroxidases, followed by treatment with Protein Block Solution (DAKO) for $20 \mathrm{~min}$ and incubation with anti-ER $\beta$ antibody for $30 \mathrm{~min}$ in a humidified chamber. After washing with 0.1 M TBST ( 0.1 M TBS containing $0.01 \%$ Tween 20), the sections were incubated with EnVision anti-rabbit (DAKO) polymer for $30 \mathrm{~min}$. Peroxidase bound to the antibody complex was visualized by treatment with 3, 3'-diaminobenzidine (DAB) chromogen substrate solution (DAKO). The DAB reaction was monitored under a microscope to determine optimal incubation time and stopped with several washes of $0.1 \mathrm{M}$ TBS. Immunolabeled sections were dehydrated in a graded ethanol series, defatted in xylene, and mounted, followed by examining with an Olympus BX51 microscope (Olympus, Japan) under bright-field illumination. Images were acquired with an Olympus DP 70 camera (Olympus).

\section{Quantitative reverse transcriptase polymerase chain reaction}

Total RNA was extracted from cell samples, and $1.5 \mu$ g aliquots of RNA were reverse-transcribed with oligo (dT)12-18 primers using a First-Strand cDNA synthesis kit (Fermentas, Grand Island, NY). Using the comparative threshold cycle $(\mathrm{Ct})$ method or the standard method, gene expression was calculated as the ratio of expression in cancer tissues to normal tissues after normalization relative to the expression of the beta-2 macroglobulin (B2M) gene in each sample. The ER $\beta$ primers were 5'- GTC AGG CAT GCG AGT AAC AA -3' (forward) and 5'- GGGAGCCCTCTTTGCTTTTA -3' (reverse), and the B2M primers were 5'- CTC GCT CCG TGG CCT TAG -3' (forward) and 5'- CAA ATG CGG CAT CTT CAA -3' (reverse). Primer sequences for expression of mitochondrial genes are provided in Table 1. All reactions were performed in triplicate.

\section{Colony-forming and sphere-formation assays}

Anchorage-independent growth was assessed by performing colony-forming assays in soft agar and sphere-formation cultures. For colony-forming assays, cells were resuspended in $1 \mathrm{ml}$ of growth medium containing $0.3 \%$ agar and plated over a layer of $0.6 \%$ agarose in growth medium. The cells were cultured at $37^{\circ} \mathrm{C}$ for 15 days, and the colonies were stained with $0.01 \%$ Crystal Violet (Sigma) for 10 minutes and counted. For sphere-formation assays, cells were seeded in ultra-low-attachment 6-well plates at a density of $10^{3}$ cells $/ \mathrm{ml}$. Sphere cultures were grown in serum-free DMEM/F12 containing $20 \mathrm{ng} / \mathrm{ml}$ epidermal growth factor and $10 \mathrm{ng} / \mathrm{ml}$ basic fibroblast growth factor.

\section{Mitochondrial chromatin immunoprecipitation}

Chromatin immunoprecipitation assays were performed using the ChIP-IT Express Enzymatic kit (Active Motif, Carlsbad, CA) according to a modified protocol for mitochondrial ChIP assays [26]. Briefly, the cells were separated into mitochondria pellets and a cytosol fraction. DNA and proteins from the isolated mitochondrial pellets were cross-linked with $1 \%$ formaldehyde and digested with the enzyme mixture provided in the kit to reduce the size of DNA fragments to $200-500 \mathrm{bp}$. The samples were immunoprecipitated with anti-ER $\beta$ and anti-HA antibodies, with $2 \mu \mathrm{g}$ of normal rabbit or mouse IgG used as the negative control. ER $\beta$ in immunoprecipitated DNA was amplified by qPCR, using the primers $5^{\prime}$ - cct ccg tga aat caa tat ccc gc - 3' (forward) and 5'- ctt att taa ggg gaa cgt gtg g -3' (reverse) and a protocol consisting of an initial denaturation at $95^{\circ} \mathrm{C}$ for 5 minutes, followed by 45 cycles of denaturation at $95^{\circ} \mathrm{C}$ for 30 seconds, annealing at $60^{\circ} \mathrm{C}$ for 30 seconds, and extension at $72^{\circ} \mathrm{C}$ for 30 seconds. The amount of immunoprecipitated DNA was normalized to the amount of starting DNA.

\section{Evaluation of tumorigenicity}

All animal experiments were approved by the animal use committee of Ulsan University. Mockexpressing or mitoER $\beta$-expressing MDA-MB-231 cells $2 \times 10^{6}$ cells per mouse) were injected into the mammary gland 3 fat pads of 8-week-old female non-obese diabetic/severe combined immunodeficient (NOD-CB17-Prkdcscid) mice. Tumor formation was monitored for approximately 8 weeks, with tumor lengths $(\mathrm{l})$ and widths $(\mathrm{w})$ measured every 3 days using digital calipers. Tumor volumes were calculated using the formula $\mathrm{V}=\mathrm{lw} 2 / 2$. Mice were anesthetized with inhaled isoflurane, a small nick was made in the skin, and 


\section{Cellular Physiology Cell Physiol Biochem 2019;52:468-485

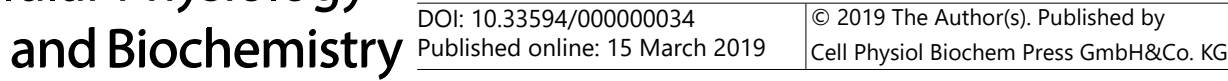 \\ Song et al.: mitoER $\beta$ Regulates Mitochondrial Function in TNBC}

the generated tumor was removed using sterile techniques. The mice were allowed to recover from surgery, and overall survival was monitored for 5 months.

\section{Statistical analysis}

Data were expressed as the means \pm SDs of three independent experiments and compared using Student's $t$ tests. All analyses were performed using SigmaPlot 12.0 software (2013, Systat Software Inc. San Jose, CA). $P$ values were calculated to assess statistical significance and are indicated as follows: ${ }^{*} P<.05$; ${ }^{* *} P$ $<.01$; and ${ }^{* * *} P<.001$.

\section{Results}

Reducing the importation of ER $\beta$ into mitochondria of breast cancer patients increases relapse frequency after surgery

To assess the function of $\operatorname{ER} \beta$ in the mitochondria of breast cancer cells, it was necessary to confirm the level of ER $\beta$ expression in patients with breast cancer. The level of ER $\beta$ mRNA was found to be $80 \%$ lower in breast cancer tissues than in adjacent normal breast tissues (Fig. 1A). Immunohistochemistry showed that ER $\beta$ staining was strong in normal breast tissue, with samples from 24 of 30 (80\%) breast cancer patients showing positive staining for ER $\beta$ (Fig. 1B). Furthermore, western blot analysis showed that ER $\beta$ expression was lower, regardless of breast cancer subtype (Fig. 1C). Analysis of the prognosis of patients following surgery and anticancer therapy showed relapse in 5 of 12 patients within 5 years, with metastases to the contralateral breast, lungs, and bones (Table 2). Moreover, ER $\beta$ expression was negatively correlated with metastatic tumor growth (Fig. 1D). Immunoblotting of fractionated proteins showed that the amount of $\operatorname{ER} \beta$ that had translocated into mitochondria was lower in tissue samples from the five patients with than from the seven without tumor relapse (Fig. 1E). Taken together, these findings suggest that mitoER $\beta$ plays a critical role in the mitochondria of normal mammary gland cells and may be used as a potential target in the development of anticancer drugs.

Involvement of Grp75 proteins in ER $\beta$ importation into mitochondria, and the effects of steroid hormones and growth factors

To identify the molecular mechanism underlying the translocation of ER $\beta$ into mitochondria, it was first necessary to identify the proteins that interact with ER $\beta$ interacting partners. Unstimulated GST-ER $\beta$-overexpressing MCF7 cell extracts were incubated with GSH beads. The supernatants were separated on a denaturing gel, the proteins were visualized by Coomassie blue staining, and the individual proteins in the complex were extracted and their identities were determined by peptide mass fingerprinting (Fig. 2A). The precipitate was found to contain glucose-regulated protein (Grp) 75, a mitochondrial chaperone protein. 


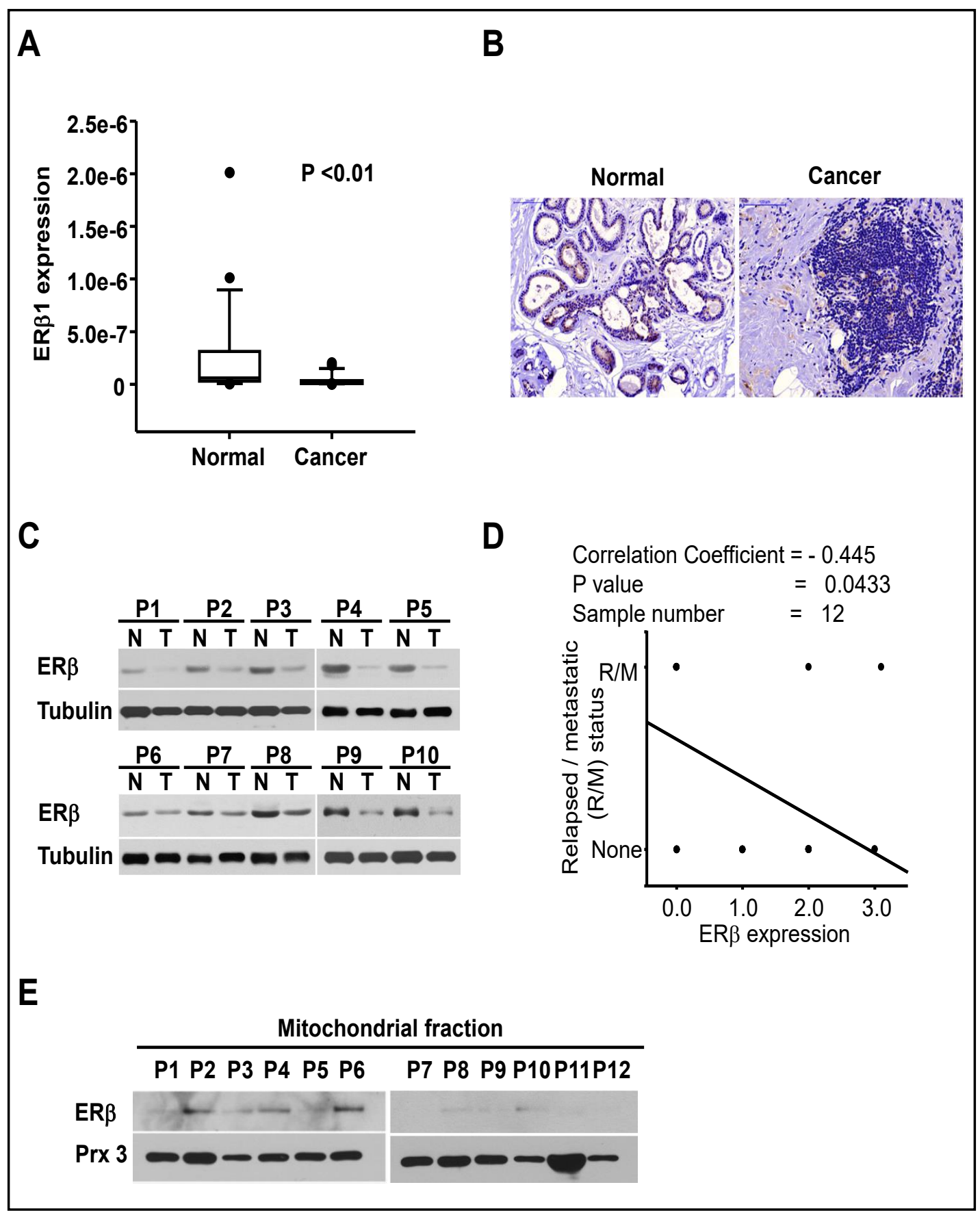

Fig. 1. Association between low expression of mitoER $\beta$ in breast tumors and breast cancer recurrence or metastasis. A. ER $\beta$ mRNA levels measured by qRT-PCR in cancer tissues and adjacent normal tissues of 30 breast cancer patients. B. ER $\beta$ protein levels measured by immunohistochemistry in breast cancers and adjacent normal tissue. C. ER $\beta$ protein levels measured by immunoblotting with anti-ER $\beta$ antibody in paired tissue samples from 10 breast cancer patients. D. Scatterplot showing a negative correlation between ER $\beta$ expression and metastasis (recurrence). Pearson correlation coefficient and $p$ values are shown in the graph. E. Immunoblotting with ER $\beta$ antibody of the mitochondrial fraction of breast cancer tissues derived from luminal A (P4), luminal B (P1, P2, P5, P6, P7, P8, P10), HER2 (P3, P11) and triple negative breast cancer $(\mathrm{P} 9, \mathrm{P} 12)$ types. Fraction purity and protein loading were assessed by Prx3 antibody. 


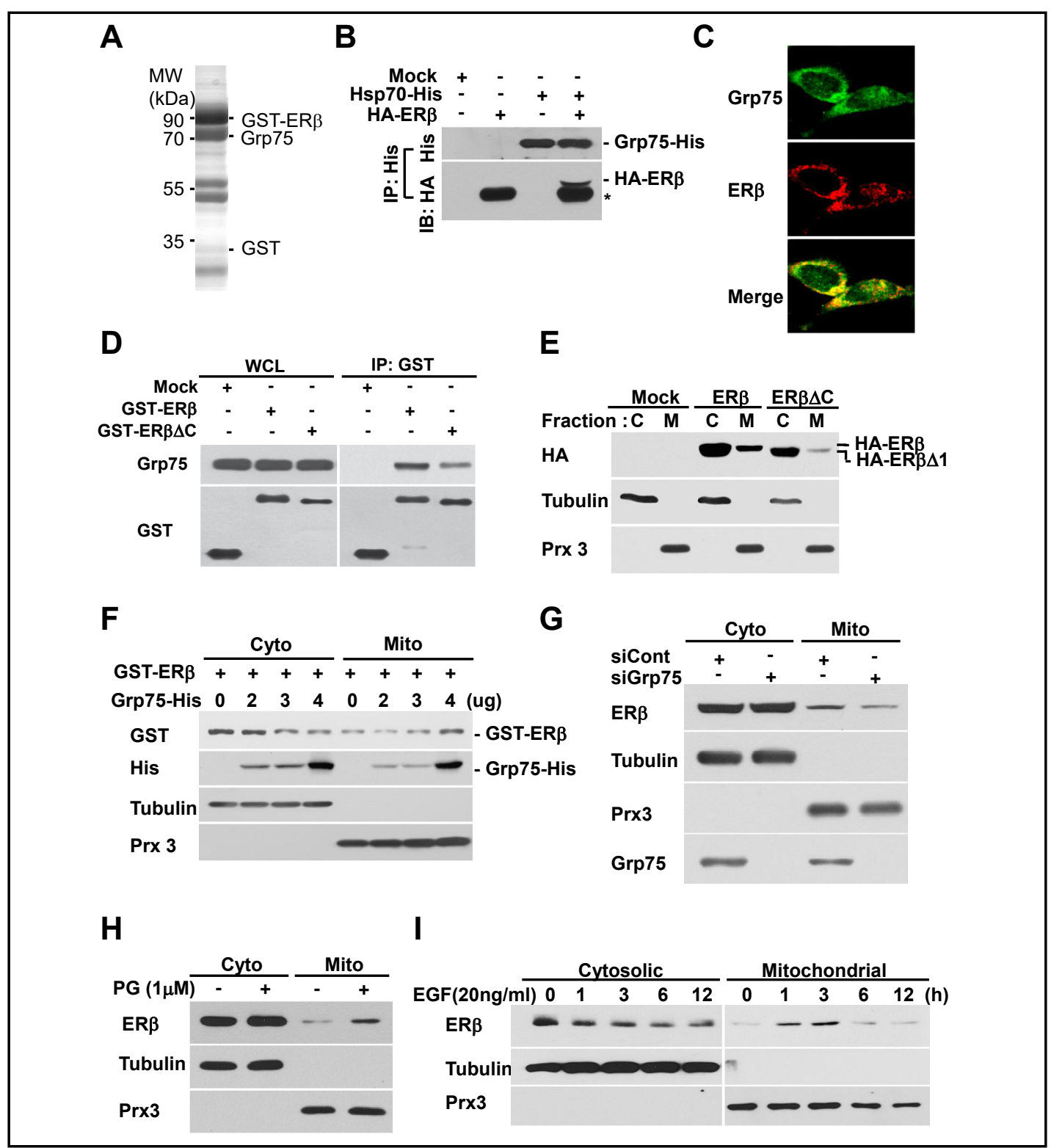

Fig. 2. ER $\beta$ interacts with Grp75 protein and translocates into mitochondria. A. ER $\beta$ interacting protein was affinity-purified using GSH-Sepharose beads and separated on a $10 \%$ denaturing gel. The Coomassiestained gel shows the proteins identified by MALDI-TOF mass spectrometry and the presence of ER $\beta$ and Grp75 in the purified complex. B. MCF7 cells were transfected with pHA-ER $\beta$ and pcDNA-Grp75-his, cell extracts were immunoprecipitated with anti-His antibody as described in the Materials and Methods section, and the precipitated proteins were subjected to immunoblotting. C. MCF7 cells were stained with the indicated antibodies and observed by confocal microscopy. D. Protein-protein interactions of ER $\beta$ or ER $\triangle \triangle \mathrm{C}$ with Grp75 in the indicated plasmid-transfected MCF7 cells. WCL, whole cell lysate. E. MCF7 cells were transfected with an ER $\beta$ - or ER $\triangle \mathrm{C}$-expressing plasmid, followed by separation into cytosolic (C) and mitochondrial (M) fractions and immunoblotting with the indicated antibodies. F. MCF7 cells were co-transfected with pEBG-GST-ER $\beta$ and pcDNA-Grp75 plasmid at the indicated doses, and separated into cytosolic (C) and mitochondrial (M) fractions. G. MCF7 cells were transfected with siRNA against the Grp75 gene or control, separated into cytosolic (C) and mitochondrial (M) fractions, and subjected to immunoblotting. H and I. MCF7 cells were treated with progesterone (PG; H) for 1 hour or epidermal growth factor (EGF; I) for the indicated times, separated into cytosolic (C) and mitochondrial (M) fractions, and subjected to immunoblotting with the indicated antibodies. 
To further verify the interaction between ER $\beta$ and Grp75, His-tagged Grp75 and HA-tagged ER $\beta$ were overexpressed and immunoprecipitated with anti-His antibody (Fig. 2B). Western blot analysis of the precipitated complex demonstrated the interaction between HA-ER $\beta$ and Grp75-His, and coimmunostaining confirmed the colocalization of ER $\beta$ and Grp75 (Fig. 2C).

To identify the binding regions of ER $\beta$ and Grp75, deletion constructs of ER $\beta$ were generated. Full-length ER $\beta$ protein contains 530 amino acids (a.a.) in several domains, including activating, DNA-binding, ligand-binding, and protein-protein interacting domains, whereas the ER $\beta \triangle \mathrm{C}$ mutant (a.a. 1-468) lacks the protein-protein interaction domain (a.a. 469-530). Coimmunoprecipitation experiments showed that $\mathrm{ER} \beta \triangle \mathrm{C}$ interacted less with Grp75 than did full-length ER $\beta$ (Fig. 2D) and that this reduced interaction resulted in reduced translocation into mitochondria (Fig. 2E). To confirm that ER $\beta$ translocation into mitochondria is mediated by interaction with Grp75, cells were treated with siRNA against the Grp75 gene or control siRNA. Following subcellular fractionation, Grp75 overexpression was found to induce ER $\beta$ translocation into mitochondria (Fig. 2F). By contrast, the depletion of Grp75 using a siRNA against Grp75 reduced the amount of ER $\beta$ imported into mitochondria (Fig. 2G). Collectively, these results provide strong experimental evidence that ER $\beta$ directly interacts with Grp75, resulting in the translocation of ER $\beta$ into mitochondria.

ERs were shown to be activated by binding of cognate estrogenic ligands and other extracellular signaling molecules, such as EGF and FGF [27, 28]. Moreover, PRs are critical effectors of ER signaling required for mammary gland development. In breast cancer, PR acts as a clinical prognostic marker of ER action [29]. Thus, to evaluate the mitochondrial translocation of ER $\beta$ in response to stimuli, MCF7 cells were stimulated with progesterone and EGF. Progesterone treatment enhanced the mitochondrial translocation of ER $\beta$ protein (Fig. 2H). In addition, EGF treatment of cells starved for $12 \mathrm{hrs}$ induced the mitochondrial translocation of ER $\beta$, which reached a maximum at $3 \mathrm{hrs}$ (Fig. 2I). Together, these results demonstrate that the mitochondrial translocation of Grp75-ER $\beta$ complex is promoted by steroid hormone and growth factor.

\section{Increased mitoER $\beta$ inhibits TNBC cell proliferation}

To evaluate the effect of mitochondria-imported ER $\beta$, we constructed mitochondriatargeted ER $\beta$ overexpressing plasmids. As shown in figures $3 \mathrm{~A}$ and $3 \mathrm{~B}$, cell proliferation was inhibited more in pHA-mitoER $\beta$-transfected MDA-MB-231 and -436 cells than in mock-transfected cells. Western blotting analysis of the amount of mitoER $\beta$ showed that overexpressed ER $\beta$ was distributed 1:1 in the cytosolic and mitochondrial fractions. Cell cycle analysis showed that overexpression of mitoER $\beta$ in both MDA-MB-231 and MDA-MB-436 cells reduced the population of cells in the $S+G_{2}+M$ phase, indicative of cell proliferation, from $48 \%$ to $34 \%$ (Fig. 3C and 3D). The effects on MDA-MB-231 cell proliferation of deletion constructs of ER $\beta$, including ER $\beta \triangle N$, consisting of a.a. 145-530, which lacks the activation domain and is unable to function as a transcription factor, and $\mathrm{ER} \beta \triangle \mathrm{C}$, consisting of a.a. 1-468, which lacks the protein-protein interaction domain and is unable to enter into mitochondria, were also assessed. Transfection of MDA-MB-231 cells with plasmid overexpressing full-length ER $\beta$ induced a marked decline in cell proliferation rate $\left(S+G_{2}+M\right.$ phase). By contrast, transfection with the deletion constructs ER $\beta \triangle N$ and $\mathrm{ER} \beta \triangle \mathrm{C}$ had no effect on proliferation rate (Fig. 3E). Collectively, these findings indicate that increased ER $\beta$ protein in mitochondria inhibits the proliferation of TNBC cells, with inhibition of proliferation mediated by mitochondrial translocated ER $\beta$, not the activation of transcription by nuclear translocated ER $\beta$.

\section{mitoER $\beta$ overexpression impairs tumor growth in vivo}

The effect of mitoER $\beta$ overexpression on modulation of tumorigenesis was assessed using an anchorage-independent growth assay. MDA-MB-231 and -436 cells overexpressing mitoER $\beta$ showed significant reductions in colony formation compared with control cells (Fig. 4A). Furthermore, sphere formation was approximately $30 \%$ lower in mitoER $\beta$ overexpressing than in control MDA-MB-231 and -436 cells (Fig. 4B). The in vivo effects of 
Fig. 3. Overexpression of mitochondriatargeting $\quad \mathrm{ER} \beta$ inhibits TNBC cell proliferation. $A$ and B. MDA-MB-231 (A) and MDA-MB-436 (B) cells were transfected with pHA-mito-ER $\beta$ or control plasmid, and cell proliferation over 72 hrs was assessed by CCK-8 assays. Mitochondrial ER $\beta$ expression was analyzed by i m m un oblotting after subcellular fractionation. $\mathrm{C}$ and D. MDA-MB-231 and MDA-MB-436 cells were transfected with pHA-mitoER $\beta$ or control plasmid, followed by assessment of cell cycle distribution. Data were analyzed by FACS (C), and the cell proliferation index (PI) was calculated and reported as described in the Materials and Methods section (D). E. MDA-MB-231 cells were transfected with pHA-ER $\beta$, pHA$\mathrm{ER} \triangle \mathrm{N}$, or pHA-ER $\triangle \mathrm{C}$ plasmid, and cell cycle distribution was analyzed using a FACScanto II.

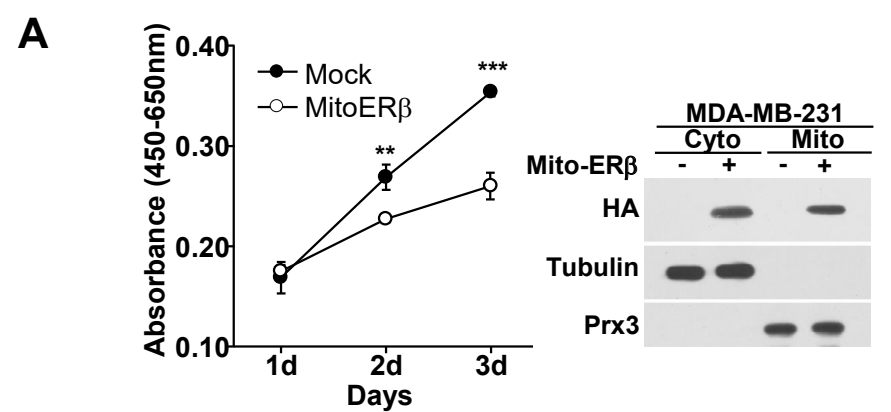

B

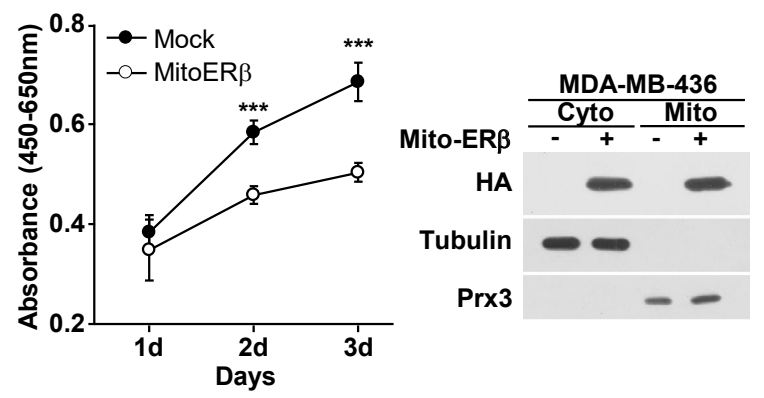

C
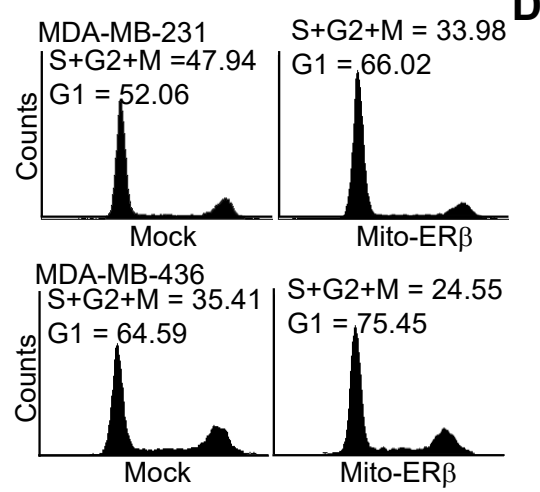

E

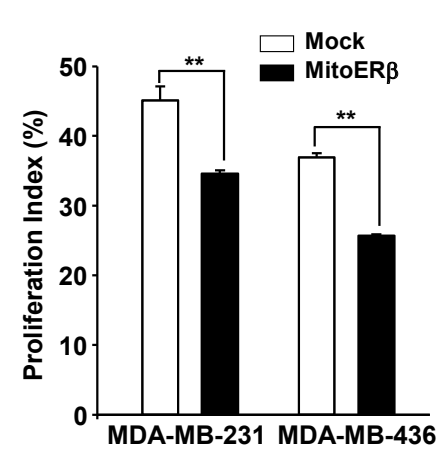

imported mitoER $\beta$ were evaluated using a mouse orthotopic xenograft model; MDA-MB-231 TNBC cells that did and did not express excess mitoER $\beta$ were engrafted into mammary fat pads of immunodeficient nude mice. Tumor volume was significantly lower following engraftment of ER $\beta$-overexpressing than control MDA-MB-231 cells (Fig. 4C). The level of ER $\beta$ expression was confirmed in tumor tissues of each group by western blotting (Fig. 4D). In assessing the effects of mitoER $\beta$ expression on survival rate, we found that the survival rate was higher in mice receiving mitoER $\beta$-overexpressing than control cells, with the higher survival rate likely due to the reduced tumor progression in mitoER $\beta$-overexpressing mice 
A

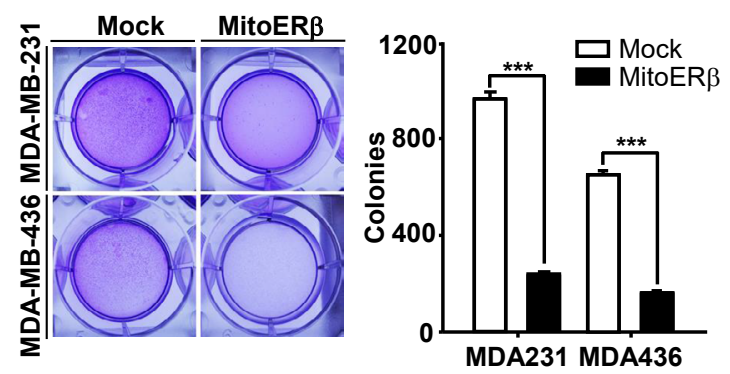

B
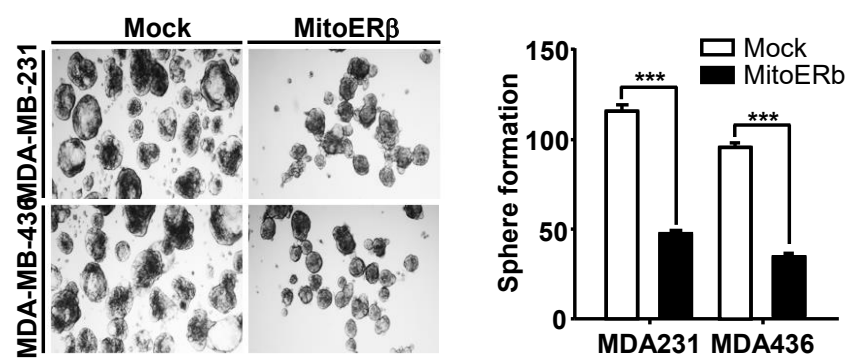

C
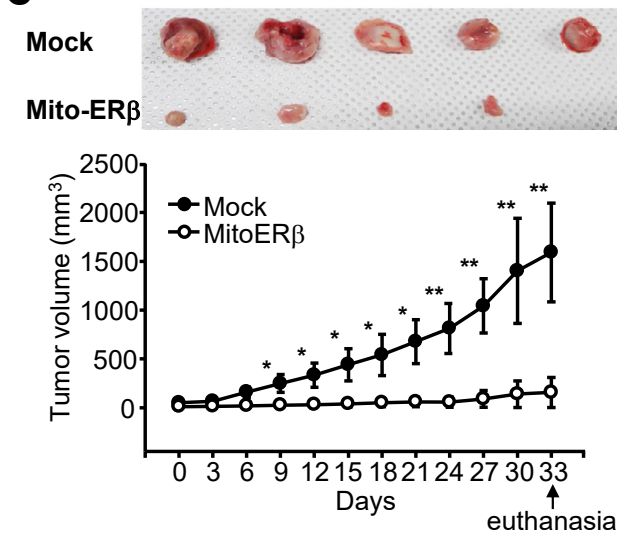

D

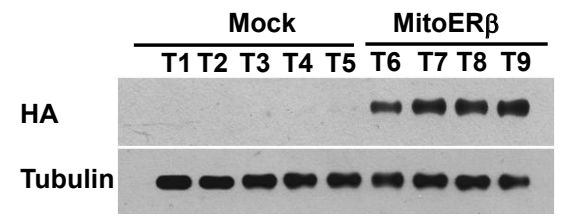

$\mathbf{E}$

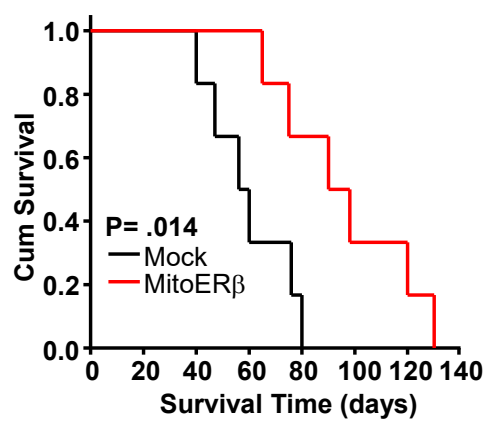

Fig. 4. mitoER $\beta$ inhibits the tumorigenesis of breast cancer cells in vitro and in vivo. A. TNBC cell lines were transfected with pHA-mito-ER $\beta$ or Mock, and the cells were subjected to colony-forming assays. The numbers of colonies generated per 10,000 cells were counted 3 weeks later. B. ER $\beta$-overexpressing and control cells were subjected to sphere-formation assays in ultra-low-attachment 96-well plates after $72 \mathrm{hrs}$. The numbers of spheroids generated per 10,000 cells were counted 2 weeks later. C-E. To determine the effects of mitoER $\beta$ on the kinetics of tumor growth, five mice each were implanted with ER $\beta$-overexpressing and control cells. Images of tumors taken from the mice in each group are presented, with the data representing the mean \pm standard error of tumor volumes recorded at 3 day intervals (C). Tumor samples from each mouse were subjected to immunoblotting with anti-ER $\beta$ antibody (D). Kaplan-Meier analysis of overall survival over time of the animals in the two groups, with between-group differences determined by the log rank test (E). 


\section{Cellular Physiology Cell Physiol Biochem 2019;52:468-485 \\ \begin{tabular}{ll|l} 
and Biochemistry $\begin{array}{l}\text { DOl: 10.33594/000000034 } \\
\text { Published online: 15 March 2019 }\end{array}$ & $\begin{array}{l}\text { O } 2019 \text { The Author(s). Published by } \\
\text { Cell Physiol Biochem Press GmbH\&Co. KG }\end{array}$ \\
\cline { 2 - 3 } & Song
\end{tabular} \\ Song et al.: mitoER $\beta$ Regulates Mitochondrial Function in TNBC}

(Fig. 4E). Taken together, these in vivo results indicate that the anticancer effects of ER $\beta$ are due to its translocation into mitochondria.

mitoER $\beta$ overexpression activates the transcription of the mitochondrial genome in ER $\beta$ depleted TNBC cells, enhancing mitochondrial function

To evaluate the function of ER $\beta$ in mitochondria, the expression of mitochondrial genes was assessed by qRT-PCR. Overexpression of mitoER $\beta$ in MDA-MB-231 and -436 TNBC cells induced the expression of 13 mitochondrial genes, whereas overexpression of ER $\beta \triangle N$ and $\mathrm{ER} \beta \triangle \mathrm{C}$ deletion mutants did not activate expression of the mitochondrial genome (Fig. $5 \mathrm{~A}$ and $5 \mathrm{~B})$. Because mitoER $\beta$ is reported to bind to ERE-like sequences in the D-loop of mtDNA [17, $18,30,31]$, chromatin immunoprecipitation assays were performed to determine whether mitoER $\beta$ functions as a transcription factor via direct binding to mtDNA. ER $\beta$ was found to bind to the D-loop of mtDNA of MCF7 luminal type breast cancer cells and MDA-MB-231 TNBC cells (Fig. 5C and 5D). TNBC cells were transfected with a mitoER $\beta$-overexpressing or control plasmid to evaluate potential differences in mitochondrial function in cells that did and did not express mitoER $\beta$. Although FACS analysis showed that mitoER $\beta$ overexpression had no effect on mitochondrial membrane potential, mitochondrial ROS and $\mathrm{Ca}^{2+}$ levels were higher in mitoER $\beta$-overexpressing than in control TNBC cells (Fig. 6A-C). Similarly, fluorescence microscopic analysis showed that mitochondrial ROS and $\mathrm{Ca}^{2+}$ levels were increased in ER $\beta$-overexpressing TNBC cells, but not in cells overexpressing ER $\beta$-deletion mutants (Fig. 6D-F). ATP production was significantly higher in ER $\beta$-overexpressing than control cells, corresponding to a significant increase in mitochondrial ROS levels (Fig. 6G). By contrast, overexpression of ER $\beta$-deletion mutants in TNBC cells had no effect on ATP levels. Collectively, these findings suggest that ER $\beta$ up-regulation in TNBC cells, which produce ATP by primary glycolysis rather than by OXPHOS, leads to ATP production via activation of the OXPHOS system resulting from transcriptional regulation in the mitochondrial genome.

\section{mitoER $\beta$ regulates mitochondrial function in normal breast cells to produce ATP by}

OXPHOS

The finding that mitoER $\beta$ induces a metabolic shift by sustained transcriptional activation of the mitochondrial genome in TNBC cells suggested that mitoER $\beta$ can maintain mitochondrial function to produce ATP in normal breast cells. Compared with normal breast MCF10A cells transfected with control siRNA, ER $\beta$ knockdown reduced membrane potential, mitochondrial ROS level, and calcium level (Fig. 7A). Conversely, overexpression of mitoER $\beta$ increased membrane potential mitochondrial ROS level, and calcium level compared with mock-transfected MCF10A cells (Fig. 7B). In addition, ATP levels were markedly higher in the mitochondria of mitoER $\beta$-overexpressing cells, whereas ER $\beta$ depletion reduced ATP production (Fig. 7C). ATP production was lower in breast cancer cells than in normal breast MCF10A cells (Fig. 7D) and was especially lower in TNBC than in luminal breast cancer cell lines and normal breast cells, as the latter produced ATP via the OXPHOS system, which was transcriptionally activated by mitoER $\beta$. These results suggest that mitoER $\beta$ maintains mitochondrial function in breast cells by transcriptional activation of mtDNA, resulting in the expression of genes encoding the component proteins of the OXPHOS machinery. Reductions in importation of ER $\beta$ protein into mitochondria may result in a metabolic shift, with breast cancer cells producing ATP via glycolysis. 
A
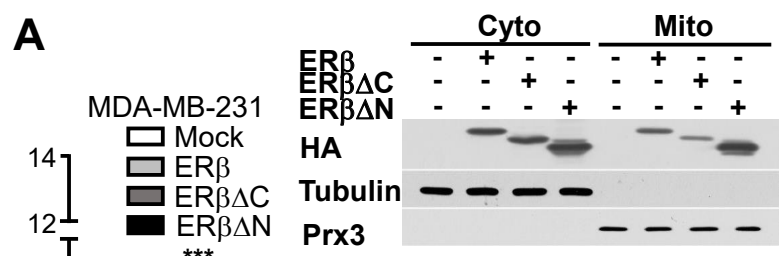

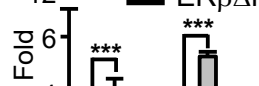

Prx3<smiles>C1CCC1</smiles>

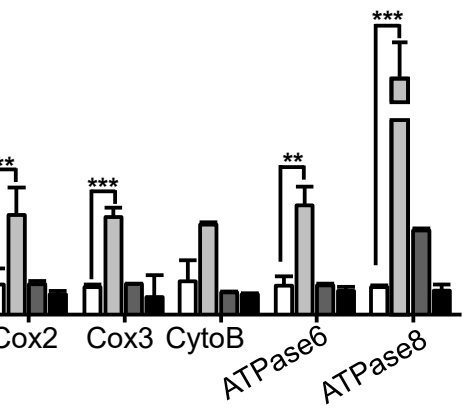

B

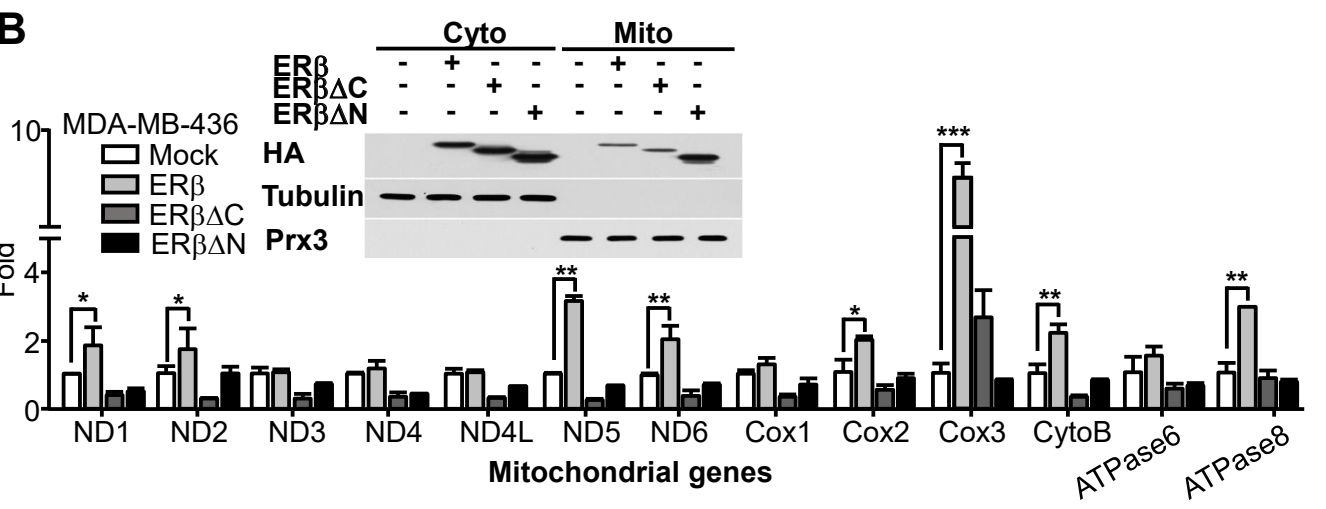

C
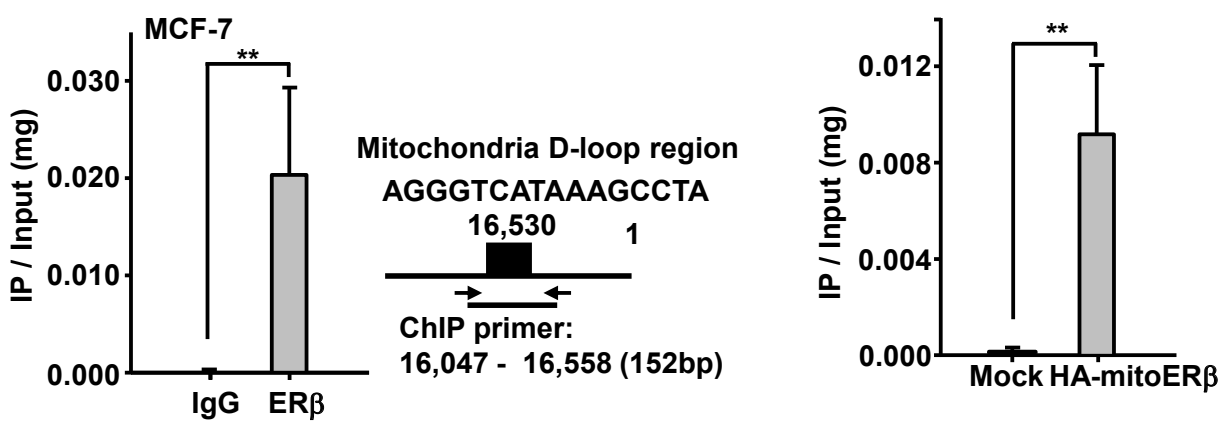

Fig. 5. mitoER $\beta$ activates the transcription of mitochondrial genes in TNBC MDA-MB-231 and - 436 cells. Quantitative RT-PCR analysis of mitochondrial gene mRNA levels in Mock-, pHA-ER $\beta$-, pHA-ER $\beta \triangle N$-, and pHA-ER $\beta \triangle$ C-transfected MDA-MB-231 (A) and MDA-MB-436 (B) TNBC cell lines. ER $\beta$ and ER $\beta \triangle N$ expression was confirmed by immunoblotting after subcellular fractionation. C. MCF7 cells were harvested for chromatin immunoprecipitation analysis using anti-ER $\beta$ antibody or normal IgG. The association of ER $\beta$ with the mitochondrial D-loop region was determined by qPCR. Right panel, Schematic view of the ER $\beta$ binding sites in the mitochondrial D-loop region. D. MDA-MB-231 cells were transfected with pHA-mito-ER $\beta$ or Mock plasmid, and the cells were harvested for chromatin immunoprecipitation analysis using an antiHA antibody. 


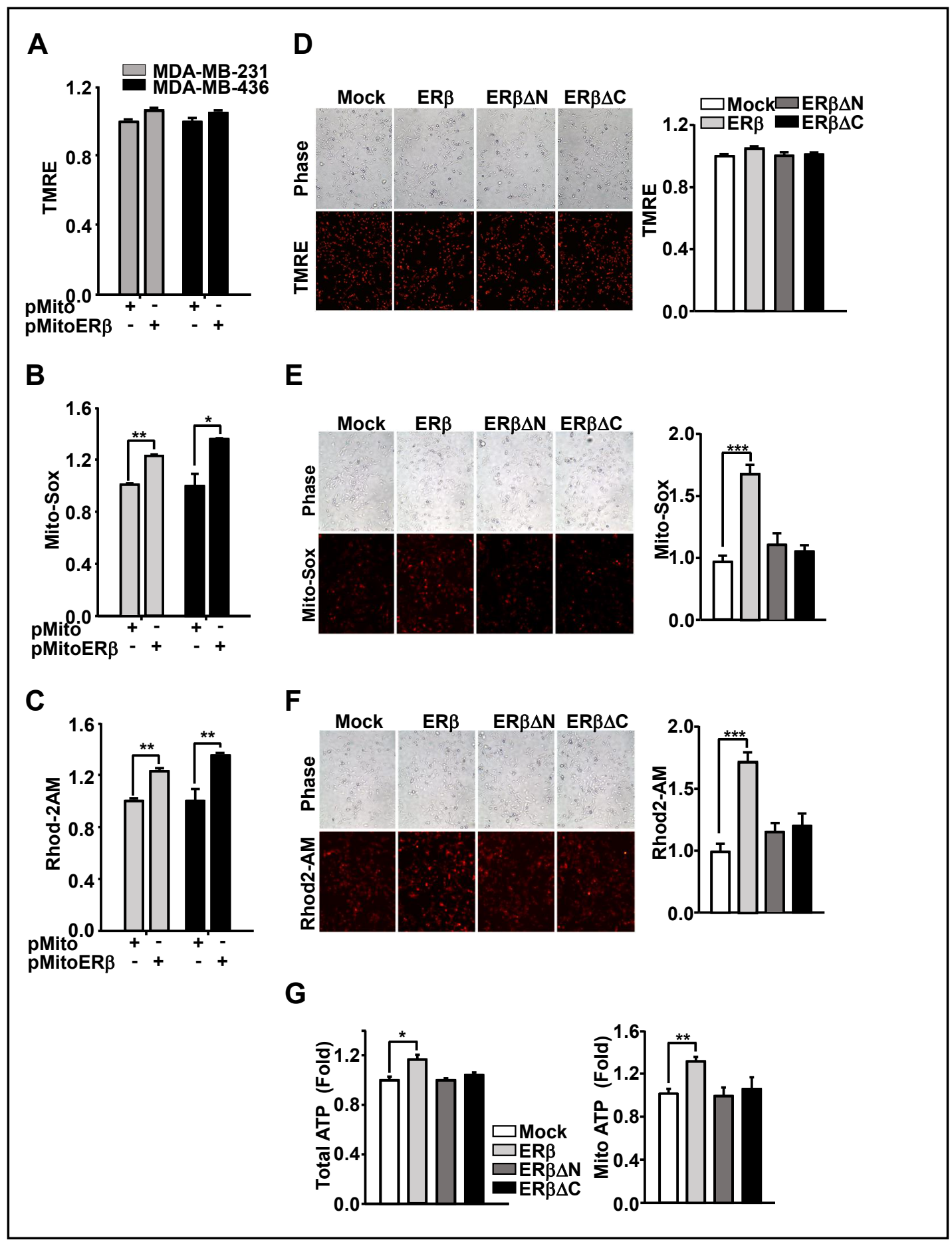

Fig. 6. mitoER $\beta$ improves the mitochondrial function in TNBC MDA-MB-231 and - 436 cells. A-C. Mitochondrial membrane potential (A), ROS levels (B), and calcium levels (C) were measured in mock- and pHA-mitoER $\beta$-transfected TNBC MDA-MB-231 and MDA-MB-436 cells. D-F. MDA-MB-231 cells were transfected with mock, ER $\beta$, and ER $\beta$ deleted mutants as indicated, and the cells were stained with TMRE (D), Mito-Sox (E), and Rhod-2AM (F). Representative fluorescent microscope images are shown, with quantified data shown as a graph in the right panel. G. MDA-MB-231 cells were transfected with mock, pHA-ER $\beta$, pHA-ER $\triangle \triangle \mathrm{N}$, and pHA-ER $\triangle \triangle \mathrm{C}$, and total and mitochondrial ATP levels were measured by quantifying the luciferase-catalyzed ATP-dependent oxidation of luciferin. 


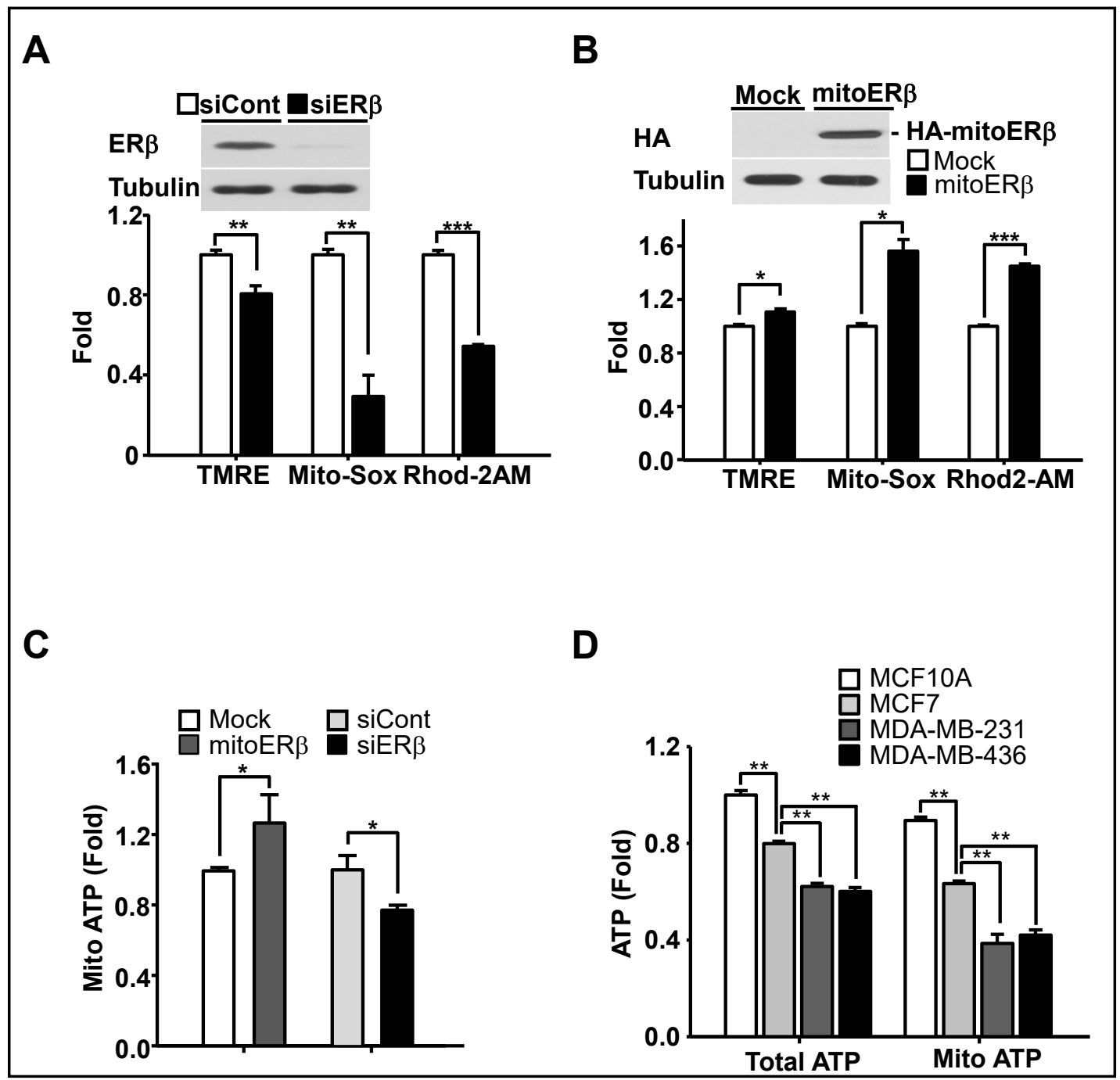

Fig. 7. Mitochondrial activity is higher in normal breast cells than in luminal breast cancer and TNBC cells. A. MCF10A normal breast cells were transfected with siRNA against the ER $\beta$ gene and control siRNA, and their mitochondrial function, membrane potential, ROS level, and calcium production level were measured by FACS analysis after staining with TMRE, Mito-Sox, and Rhod-2AM dye, respectively. B. MCF10A cells were transfected with mock and pHA-mito-ER $\beta$ plasmids, and mitochondrial function was assessed as described in Fig. 7A. C. MCF10A cells were transfected with mock and pHA-mito-ER $\beta$ to overexpress ER $\beta$, or with siRNA against the ER $\beta$ gene and control, and their mitochondrial ATP level was measured by quantifying the luciferase-catalyzed ATP-dependent oxidation of luciferin. D. Measurement of total and mitochondrial ATP levels in breast cancer and normal breast cells by quantifying the luciferase-catalyzed ATP-dependent oxidation of luciferin.

\section{Discussion}

The current study found that ER $\beta$ plays a critical role in maintaining mitochondrial function via transcriptional activation in mitochondria, thereby promoting mitochondrial homeostasis in epithelial cells of the mammary gland. This study also showed that a reduction in expression of ER $\beta$ especially of mitoER $\beta$ resulted in metastatic tumor progression after surgical treatment of patients with breast cancer. Mitochondrial function was poorer in TNBC than in normal epithelial cells, which is likely due, in part, to the up-regulated expression of mitochondrial genes by translocation of ER $\beta$. 


\section{Cellular Physiology Cell Physiol Biochem 2019;52:468-485 \\ \begin{tabular}{ll|l} 
and Biochemistry & $\begin{array}{l}\text { DOl: 10.33594/000000034 } \\
\text { Published online: } 15 \text { March } 2019\end{array}$ & $\begin{array}{l}\text { C } 2019 \text { The Author(s). Published by } \\
\text { Cell Physiol Biochem Press GmbH\&Co. KG }\end{array}$
\end{tabular} \\ Song et al.: mitoER $\beta$ Regulates Mitochondrial Function in TNBC}

Several prognostic and predictive markers have been used in treating patients with breast cancer. Despite adjuvant therapy tailored to the subtype of breast cancer, many patients experience tumor recurrence. This study showed that breast cancer recurrence rates were higher in patients with reduced ER $\beta$ expression and reduced ER $\beta$ translocation into mitochondria than in patients with high levels of ER $\beta$ expression and mitoER $\beta$ protein (Fig. 1). Moreover, overexpression of mitoER $\beta$ inhibited TNBC cell proliferation. These results indicate that levels of mitochondria-targeted ER $\beta$ may be a prognostic marker in patients with breast cancer.

The import of ER $\beta$ into mitochondria was facilitated by the construction of ER $\beta$ containing the mitochondria-targeting sequence of mitochondrial SOD2 protein. To enhance the mitochondrial function of ER $\beta$ translocated into mitochondria but not nuclear ER $\beta$, we constructed the ER $\beta$-deletion mutants $\operatorname{ER} \beta \triangle N$ (145-530 a.a.) and $\operatorname{ER} \beta \triangle C$ (1-468 a.a.). $\mathrm{ER} \beta \triangle \mathrm{N}$ does not contain the activation function domain of ER $\beta$ (a.a. 1-144) and cannot function as a transcription factor in the nucleus or mitochondria. $E R \beta \triangle C$ does not contain the protein-protein interaction domain of ER $\beta$ (a.a. 469-530) and cannot translocate into mitochondria due to its inability to interact with the molecular chaperone Grp75. Use of these deletion mutants showed that importation into mitochondria and transcription factor activity are required for ER $\beta$ to activate mitochondrial gene expression.

Mitochondrial energy metabolism in breast cancer subtypes is reported to depend on mitochondrial gene expression and function [32-34]. Altered expression of OXPHOS subunits resulted in mitochondrial structural injury and impaired ATP content in a breast-infiltrating ductal carcinoma (IDC). Similarly, our findings showed that mitoER $\beta$ bound to the D-loop region of the mitochondrial genome and contributed to the activation of mitochondrial gene transcription.

The metabolic shift in cancer cells may facilitate the uptake and incorporation of more nutrients into cell building blocks, such as amino acids and nucleotides, required by highly proliferating cells. Due to mitochondrial dysfunction, cancer cells tend to produce ATP via glycolysis, whereas normal cells produce ATP by OXPHOS in mitochondria. Some cancer cells use OXPHOS as their primary system of energy metabolism, whereas others are heavily dependent on glycolysis. Alterations of mitochondrial function in cancer cells are critical determinants of energy metabolism via glycolysis [35]. Therefore, a better understanding of energy metabolism in cancer cells may be useful in developing new agents to treat TNBC. Levels of ATP production differed among the different breast cancer subtypes, including luminal type and TNBC, and normal breast epithelial cells, being especially lower in ER $\beta$ depleted TNBC cells than in luminal type MCF7 cells and MCF10A normal breast epithelial cells. This study confirmed that ER $\beta$ overexpression caused tumor regression and regulated mitochondrial transcription, strongly indicating that ER $\beta$ plays an important role in the mitochondria of breast epithelial cells. These findings suggest that mitoER $\beta$ up-regulation in TNBC cells ensures proper mitochondrial transcription, maintaining ATP production by the OXPHOS system. These results also suggest that agents that promote mitoER $\beta$ overexpression, combined with an anticancer drug, may be a novel and promising therapy for patients with TNBC.

\section{Conclusion}

To our knowledge, this study is the first to report that ER $\beta$ protein regulates mitochondrial function in normal breast epithelial cells. Reduced mitoER $\beta$ expression resulted in the breakdown of mitochondrial activity in TNBC cells, increasing their proliferation via glycolysis. Up-regulation of mitoER $\beta$ activated the OXPHOS system and inhibited the proliferation of TNBC cells. Treatment with compounds that improve mitochondrial function, along with classical anticancer drugs, may have potential utility as a promising novel anticancer therapy in patients with TNBC. 


\section{Cellular Physiology Cell Physiol Biochem 2019;52:468-485 \begin{tabular}{l|l} 
DOI: 10.33594/000000034 & (c) 2019 The Author(s). Published by
\end{tabular} and Biochemistry Published online: 15 March $2019 \quad$ Cell Physiol Biochem Press GmbH\&Co. KG \\ Song et al.: mitoER $\beta$ Regulates Mitochondrial Function in TNBC}

\section{Acknowledgements}

Author contributions: I.-S. S., and S.-W. J., designed research; I.-S. S., Y. J. J., J. E. K., and S. H. J., performed research; I.-S. S., Y. J. J., J. H., T. H. K., and S.-W. J. analysed data; and I.-S. S., and T. H. K., and S.-W. J. wrote the paper. This work was supported by grants obtained from the Priority Research Centers Program (2010-0020224) and the Basic Science Research Program through the National Research Foundation of Korea (NRF) funded by the Ministry of Education (NRF-2015R1D1A1A01058022) and (NRF-2018R1D1A1B07044392).

\section{Disclosure Statement}

No potential conflicts of interest were disclosed.

\section{References}

- 1 Lehmann BD, Bauer JA, Chen X, Sanders ME, Chakravarthy AB, Shyr Y, Pietenpol JA: Identification of human triple-negative breast cancer subtypes and preclinical models for selection of targeted therapies. J Clin Invest 2011;121:2750-2767.

- 2 Dent R, Trudeau M, Pritchard KI, Hanna WM, Kahn HK, Sawka CA, Lickley LA, Rawlinson E, Sun P, Narod SA: Triple-negative breast cancer: clinical features and patterns of recurrence. Clin Cancer Res 2007;13:44294434.

- 3 Song IS, Kim HK, Lee SR, Jeong SH, Kim N, Ko KS, Rhee BD, Han J: Mitochondrial modulation decreases the bortezomib-resistance in multiple myeloma cells. Int J Cancer 2013;133:1357-1367.

- 4 Song IS, Jeong YJ, Jeong SH, Heo HJ, Kim HK, Lee SR, Ko TH, Youm JB, Kim N, Ko KS, Rhee BD, Han J: Combination treatment with 2-methoxyestradiol overcomes bortezomib resistance of multiple myeloma cells. Exp Mol Med 2013;45:e50.

- 5 Fulda S, Galluzzi L, Kroemer G: Targeting mitochondria for cancer therapy. Nat Rev Drug Discov 2010;9:447-464.

- 6 Song IS, Kim HK, Jeong SH, Lee SR, Kim N, Rhee BD, Ko KS, Han J: Mitochondrial peroxiredoxin III is a potential target for cancer therapy. Int J Mol Sci 2011;12:7163-7185.

7 Attardi G, Schatz G: Biogenesis of mitochondria. Annu Rev Cell Biol 1988;4:289-333.

- 8 Greaves LC, Reeve AK, Taylor RW, Turnbull DM: Mitochondrial DNA and disease. J Pathol 2012;226:274286.

- 9 Kujoth GC, Hiona A, Pugh TD, Someya S, Panzer K, Wohlgemuth SE, Hofer T, Seo AY, Sullivan R, Jobling WA, Morrow JD, Van Remmen H, Sedivy JM, Yamasoba T, Tanokura M, Weindruch R, Leeuwenburgh C, Prolla TA: Mitochondrial DNA mutations, oxidative stress, and apoptosis in mammalian aging. Science 2005;309:481484.

- 10 Petros JA, Baumann AK, Ruiz-Pesini E, Amin MB, Sun CQ, Hall J, Lim S, Issa MM, Flanders WD, Hosseini SH, Marshall FF, Wallace DC: mtDNA mutations increase tumorigenicity in prostate cancer. Proc Natl Acad Sci U S A 2005;102:719-724.

- 11 Tseng LM, Yin PH, Chi CW, Hsu CY, Wu CW, Lee LM, Wei YH, Lee HC: Mitochondrial DNA mutations and mitochondrial DNA depletion in breast cancer. Genes Chromosomes Cancer 2006;45:629-638.

- 12 Herrmann JM, Stuart RA, Craig EA, Neupert W: Mitochondrial heat shock protein 70, a molecular chaperone for proteins encoded by mitochondrial DNA. J Cell Biol 1994;127:893-902.

13 Wiechmann K, Muller H, Konig S, Wielsch N, Svatos A, Jauch J, Werz O: Mitochondrial Chaperonin HSP60 Is the Apoptosis-Related Target for Myrtucommulone. Cell Chem Biol 2017;24:614-623.e6.

- 14 Baines CP, Kaiser RA, Purcell NH, Blair NS, Osinska H, Hambleton MA, Brunskill EW, Sayen MR, Gottlieb RA, Dorn GW, Robbins J, Molkentin JD: Loss of cyclophilin D reveals a critical role for mitochondrial permeability transition in cell death. Nature 2005;434:658-662.

- 15 Kirichok Y, Krapivinsky G, Clapham DE: The mitochondrial calcium uniporter is a highly selective ion channel. Nature 2004;427:360-364. 


\section{Cellular Physiology Cell Physiol Biochem 2019;52:468-485 \begin{tabular}{c|c|c|c|}
\hline DOI: 10.33594/000000034 2019 The Author(s). Published by \\
and Biochemistry Published
\end{tabular} and Biochemistry Published online: 15 March 2019 Cell Physiol Biochem Press GmbH\&Co. KG \\ Song et al.: mitoER $\beta$ Regulates Mitochondrial Function in TNBC}

- 16 Yang SH, Liu R, Perez EJ, Wen Y, Stevens SM, Jr., Valencia T, Brun-Zinkernagel AM, Prokai L, Will Y, Dykens J, Koulen P, Simpkins JW: Mitochondrial localization of estrogen receptor beta. Proc Natl Acad Sci U S A 2004;101:4130-4135.

- 17 Chen JQ Eshete M, Alworth WL, Yager JD: Binding of MCF-7 cell mitochondrial proteins and recombinant human estrogen receptors alpha and beta to human mitochondrial DNA estrogen response elements. J Cell Biochem 2004;93:358-373.

- 18 Demonacos CV, Karayanni N, Hatzoglou E, Tsiriyiotis C, Spandidos DA, Sekeris CE: Mitochondrial genes as sites of primary action of steroid hormones. Steroids 1996;61:226-232.

- 19 Chen JQ Delannoy M, Cooke C, Yager JD: Mitochondrial localization of ERalpha and ERbeta in human MCF7 cells. Am J Physiol Endocrinol Metab 2004;286:E1011-E1022.

20 Bado I, Nikolos F, Rajapaksa G, Gustafsson JA, Thomas C: ERbeta decreases the invasiveness of triplenegative breast cancer cells by regulating mutant p53 oncogenic function. Oncotarget 2016;7:1359913611.

21 Sugiura H, Toyama T, Hara Y, Zhang Z, Kobayashi S, Fujii Y, Iwase H, Yamashita H: Expression of estrogen receptor beta wild-type and its variant ERbetacx/beta2 is correlated with better prognosis in breast cancer. Jpn J Clin Oncol 2007;37:820-828.

- 22 Saji S, Hirose M, Toi M: Clinical significance of estrogen receptor beta in breast cancer. Cancer Chemother Pharmacol 2005;56:21-26.

- 23 Roger P, Sahla ME, Makela S, Gustafsson JA, Baldet P, Rochefort H: Decreased expression of estrogen receptor beta protein in proliferative preinvasive mammary tumors. Cancer Res 2001;61:2537-2541.

24 Palmieri C, Cheng GJ, Saji S, Zelada-Hedman M, Warri A, Weihua Z, Van Noorden S, Wahlstrom T, Coombes RC, Warner M, Gustafsson JA: Estrogen receptor beta in breast cancer. Endocr Relat Cancer 2002;9:1-13.

25 Speirs V, Skliris GP, Burdall SE, Carder PJ: Distinct expression patterns of ER alpha and ER beta in normal human mammary gland. J Clin Pathol 2002;55:371-374.

26 Macias E, Rao D, Carbajal S, Kiguchi K, DiGiovanni J: Stat3 binds to mtDNA and regulates mitochondrial gene expression in keratinocytes. J Invest Dermatol 2014;134:1971-1980.

27 Bunone G, Briand PA, Miksicek RJ, Picard D: Activation of the unliganded estrogen receptor by EGF involves the MAP kinase pathway and direct phosphorylation. EMBO J 1996;15:2174-2183.

28 Gehm BD, McAndrews JM, Jordan VC, Jameson JL: EGF activates highly selective estrogen-responsive reporter plasmids by an ER-independent pathway. Mol Cell Endocrinol 2000;159:53-62.

29 Diep CH, Ahrendt H, Lange CA: Progesterone induces progesterone receptor gene (PGR) expression via rapid activation of protein kinase pathways required for cooperative estrogen receptor alpha (ER) and progesterone receptor (PR) genomic action at ER/PR target genes. Steroids 2016;114:48-58.

- 30 Carroll JS, Meyer CA, Song J, Li W, Geistlinger TR, Eeckhoute J, Brodsky AS, Keeton EK, Fertuck KC, Hall GF, Wang Q, Bekiranov S, Sementchenko V, Fox EA, Silver PA, Gingeras TR, Liu XS, Brown M: Genome-wide analysis of estrogen receptor binding sites. Nat Genet 2006;38:1289-1297.

31 Liao TL, Tzeng CR, Yu CL, Wang YP, Kao SH: Estrogen receptor-beta in mitochondria: implications for mitochondrial bioenergetics and tumorigenesis. Ann N Y Acad Sci 2015;1350:52-60.

32 Putignani L, Raffa S, Pescosolido R, Rizza T, Del Chierico F, Leone L, Aimati L, Signore F, Carrozzo R, Callea F, Torrisi MR, Grammatico P: Preliminary evidences on mitochondrial injury and impaired oxidative metabolism in breast cancer. Mitochondrion 2012;12:363-369.

33 Li LD, Sun HF, Liu XX, Gao SP, Jiang HL, Hu X, Jin W: Down-Regulation of NDUFB9 Promotes Breast Cancer Cell Proliferation, Metastasis by Mediating Mitochondrial Metabolism. PLoS One 2015;10:e0144441.

34 Whitaker-Menezes D, Martinez-Outschoorn UE, Flomenberg N, Birbe RC, Witkiewicz AK, Howell A, Pavlides S, Tsirigos A, Ertel A, Pestell RG, Broda P, Minetti C, Lisanti MP, Sotgia F: Hyperactivation of oxidative mitochondrial metabolism in epithelial cancer cells in situ: visualizing the therapeutic effects of metformin in tumor tissue. Cell Cycle 2011;10:4047-4064.

- 35 Birsoy K, Possemato R, Lorbeer FK, Bayraktar EC, Thiru P, Yucel B, Wang T, Chen WW, Clish CB, Sabatini DM: Metabolic determinants of cancer cell sensitivity to glucose limitation and biguanides. Nature 2014;508:108-112. 